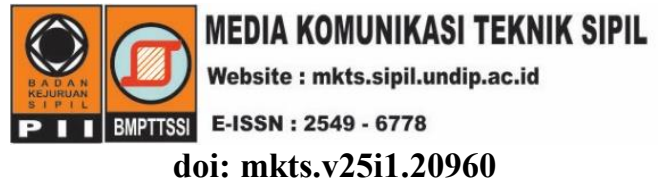

\title{
Analisis Numerik Perilaku Rangka Beton Bertulang dengan Dinding Pengisi
}

\author{
"Ida Ayu Made Budiwati, Ida Bagus Dharma Giri \\ Fakultas Teknik, Universitas Udayana, Badung Bali \\ *idabudiwati@unud.ac.id
}

Received: 7 November 2018 Revised: 8 Maret 2019 Accepted: 13 Maret 2019

\begin{abstract}
The behavior of reinforced concrete frame with infill wall (RDP) has been studied numerically by modeling the RDP structure using the LUSAS software. The results were compared to other researchers' results that conducted laboratory test and used SAP programs. The results of analysis using SAP show that the proposed model that subjected to load up to the maximum limit show similar behavior to the laboratory tests results in which parameters such as secant modulus for concrete and wall materials based on graphs of stress-strain relationships and a reduction in moment of inertia due to the crack of beam-column are taken into account. The model using LUSAS did not adopt this method instead applied plastic elastic material and non-linear analysis. The results of the analysis are still not in proportional to the magnitude of the laboratory test results, but the behavior of the load and deflection indicates similar form. The analysis models show the maximum stress points that occur on the wall similar to that with the pattern of failure in laboratory testing. The maximum stress occurs at the opening corner and the beam column joint corner that is in line with the results of laboratory testing.
\end{abstract}

Keywords: Infill wall, nonlinear material, plane stress element, reinforced concrete frame

\begin{abstract}
Abstrak
Kajian perilaku struktur rangka beton bertulang dengan dinding pengisi (RDP) telah dilakukan secara numerik dengan memodel struktur RDP dan membandingkannya dengan hasil pengujian laboratorium menggunakan program SAP oleh peneliti lain. Pemodelan dilakukan menggunakan software LUSAS. Hasil analisis dengan SAP menunjukkan bahwa usulan model yang dikenakan beban sampai batas maksimum menghasilkan perilaku yang serupa dengan hasil pengujian laboratorium, dimana pada analisis digunakan modulus secant untuk material beton dan dinding berdasarkan grafik hubungan tegangan-regangan, dan diperhitungkan pengurangan momen inersia akibat penampang balok-kolom retak. Model menggunakan LUSAS tidak mengadopsi cara tersebut tetapi menerapkan material elastis plastis dan analisis non linier. Hasil analisis berupa simpangan belum sebanding dengan hasil uji laboratorium tetapi perilaku beban dan simpangan menunjukkan kesesuaian bentuk. Tegangan hasil analisis menunjukkan kesesuaian pola namun nilai masih berbeda. Model analisis dapat menunjukkan posisi tegangan maksimum yang terjadi pada dinding sesuai dengan pola kegagalan pada pengujian laboratorium. Tegangan maksimum terjadi pada sudut bukaan dan sudut dinding pertemuan balok dan kolom sesuai dengan hasil pengujian laboratorium.
\end{abstract}

Kata kunci: Dinding pengisi, non linier material, plane stress element, rangka beton bertulang

\section{Pendahuluan}

Struktur rangka dinding pengisi (RDP)/infilled frame merupakan struktur yang terdiri atas kolom dan balok berbahan baja atau beton bertulang dengan dinding pengisi terbuat dari pasangan bata/batako (masonry) atau bahan lain. Dinding yang berada di antara struktur rangka akan berinteraksi sehingga mengubah kekakuan struktur tersebut terutama saat menerima beban lateral akibat gempa (Meharbi \& Shing, 2003).

Penelitian tentang kontribusi dinding terhadap perilaku struktur menunjukkan bahwa kekakuan struktur dibandingkan dengan open frame (OF) meningkat dengan adanya dinding pengisi 
walaupun dinding berlubang dengan adanya pintu dan jendela. Dalam analisis struktur kontribusi dinding diadopsi dengan pendekatan sederhana menggunakan strat diagonal. Permasalahan yang masih didebatkan yaitu lebar efektif strat yang digunakan. Properti dari material dan geometri dinding diperlukan dalam analisis struktur (braced frame analysis) untuk menentukan peningkatan kekakuan (Agarwal \& Manish, 2006).

Metode analisis dapat dilakukan dengan software berbasis elemen hingga untuk menganalisis struktur rangka dinding pengisi baik menggunakan elemen shell (micro) atau strat diagonal (macro). Dari kedua elemen tersebut, struktur rangka dinding pengisi penuh ataupun berlubang dimodel menggunakan single dan multi strat diagonal paling populer sudah banyak dilakukan, diantaranya oleh Mondal \& Jain (2008), Amato et al. (2009), Samoilă (2012), Sigmund \& Penava (2013), dan Budiwati \& Sukrawa (2017). Berbagai penggunaan elemen micro dalam analisis struktur RDP telah dilakukan diantaranya oleh Asteris (2008) yang melakukan studi analitikal dan Akhoundi et al. (2015), menggunakan software DIANA.

Dengan menggunakan elemen shell, Dorji (2009) melakukan penelitian terhadap struktur OF dan RDP. Pemodelan dinding pengisi menggunakan elemen shell dengan menyertakan elemen gap. Hasil penelitiannya menunjukkan bahwa pengaruh dinding pengisi terhadap performa struktur sangat signifikan. Kakaletsis \& Karayannis (2009) melakukan eksperimen RDP dengan bukaan pintu dan jendela dan struktur rangka beton bertulang satu tingkat dan menyatakan bahwa struktur RDP berlubang $25 \%$ sampai $50 \%$ dari panjang dinding pengisi menyebabkan pengurangan kekakuan awal rata-rata sebesar $26 \%$ sampai $30 \%$.

Penelitian untuk analisis rangka dinding pengisi dengan adanya konfigurasi berbagai macam bukaan yang dimodel dengan elemen shell menggunakan software SAP dilakukan oleh Sukrawa et al. (2014). Hasil penelitiannya menunjukkan bahwa usulan model yang dikenakan beban sampai batas maksimum menghasilkan perilaku yang sama dengan hasil pengujian laboratorium. Namun, pasca beban puncak model analisis belum bisa menirukan perilaku kegagalan struktur seperti yang ditunjukkan oleh hasil pengujian laboratorium peneliti lain, sehingga struktur yang dimodel tidak pernah runtuh.

Pengaruh degradasi material tidak diperhitungkan langsung dalam analisis tetapi parameter yang digunakan berupa modulus secant (Esi) untuk material beton dan dinding yang bersifat nonlinier sesuai grafik hubungan tegangan-regangan menurut
Kaushik et al. (2007), serta penurunan momen inersia (I) penampang balok-kolom saat retak diperhitungkan secara manual dan diperbaiki besarannya sebanding dengan besar beban yang diaplikasikan.

Keberadaan software berbasis elemen hingga yang lain memungkinkan untuk melakukan analisis dengan mempertimbangkan non linier geometri ataupun non linier material. Pada makalah ini dilaporkan hasil analisis rangka beton bertulang dengan dinding pengisi menggunakan software LUSAS. Masalah yang dirumuskan dalam studi analisis ini adalah bagaimanakah pemodelan struktur rangka beton bertulang dengan dinding pengisi sehingga dapat menirukan hasil pengujian pada laboratorium berupa hubungan beban lateraldeformasi dan tegangan pada dinding.

\section{Rangka dinding pengisi}

Dinding yang dianalisis sebagai komponen struktur disebut sebagai Dinding Pengisi (DP) dan struktur dengan dinding pengisi disebut Rangka Dinding Pengisi (RDP). Struktur RDP memiliki inersia yang besar, sehingga perilakunya berbeda dengan rangka terbuka (OF). Karena itu diperlukan metode dan model analisis yang mampu memperhitungkan interaksi antara DP dan sekelilingnya serta memperhitungkan sifat material yang non linier dan getas. Secara garis besar, pemodelan RDP dikelompokan menjadi dua yaitu model makro (menggunakan strat diagonal) dan model mikro berupa model elemen hingga menggunakan elemen shell.

Perkembangan metode elemen hingga memungkinkan pemodelan mikro dari DP dalam kerangka dilakukan lebih detail dimana rangka dimodel dengan elemen batang (frame/beam), DP dimodel dengan elemen bidang (plane) dan bidang kontak antara rangka dan DP dimodel dengan elemen interface atau elemen join satu dimensi. Mallick \& Severn (1967) dalam Asteris (2008), pertama kali mengusulkan model elemen hingga (MEH) untuk RDP dimana interaksi antara rangka dengan DP sepanjang bidang kontak (interface) hanya berupa gaya normal. Hal ini diatasi dengan memodel rangka sebagai elemen beam tanpa deformasi aksial dan DP dimodel sebagai elemen segi empat linier elastik dengan 2 derajat kebebasan (DOF) pada keempat titik nodalnya. Model ini diakui dapat memberikan hasil yang bersesuaian dengan hasil pengujian laboratorium dengan batasan rasio tinggi dan lebar DP tidak lebih dari dua. (Dorji, 2009) memodel DP sebagai shell dan menggunakan elemen kontak sebagai hubungan pada permukaan antara rangka dan DP. Elemen kontak yang digunakan adalah elemen Gap yang 
merupakan salah satu elemen link yang tersedia dalam program software SAP2000. Persamaan yang menyatakan hubungan antara kekakuan dinding dan kekakuan dari elemen gap $(\mathrm{Kg})$ yang diusulkan oleh Dorji (2009) yaitu.

$$
\mathrm{Kg}=0,0378 \mathrm{Ki}+347
$$

dimana, $\mathrm{Ki}\left(=\mathrm{Ei} \mathrm{i}^{\mathrm{t}}\right)$ adalah kekakuan dari DP, Ei adalah modulus elastisitas DP, dan $t$ adalah tebal DP.

Kakaletsis \& Karayannis (2009) melakukan penelitian laboratorium mengenai perilaku struktur rangka dinding pengisi berlubang. Dalam penelitiannya, terdapat sepuluh specimens yang diuji, struktur rangka tanpa dinding pengisi (OF), struktur RDP dengan dinding Solid, dan struktur RDP dengan lubang. Parameter yang ditinjau yaitu bentuk dan ukuran lubang.

Terdapat tiga specimens bukaan jendela dengan ukuran perbandingan lebar lubang dan tinggi dinding sebesar 0,$25 ; 0,38 ; 0,50$ dan tiga specimens bukaan pintu dengan ukuran perbandingan sebesar 0,$25 ; 0,38$; dan 0,50 . Selain itu, ada dua specimens menggunakan parameter untuk lokasi lubang pada struktur rangka dengan perbandingan $\mathrm{x} / \mathrm{l}$ sebesar 0.167. Dimana, 1 adalah panjang dinding pasangan bata dan $\mathrm{x}$ adalah jarak antara garis pusat dari bukaan ke tepi dinding pengisi. RDP yang diuji memiliki dimensi balok (100x200) mm dan dimensi kolom (150x150) mm. Dinding pasangan bata memiliki ketinggian $(\mathrm{H})=800 \mathrm{~mm}$ dan panjang (l) $=1200 \mathrm{~mm}$, dengan tebal $60 \mathrm{~mm}$. Karakteristik material yang digunakan untuk dinding yaitu kuat tekan 5,11 MPa, modulus elastisitas 670,30 Mpa, modulus geser $259.39 \mathrm{MPa}$, dan Koefisien gesekan 0,77. Kuat tekan beton digunakan 28.51 MPa.

Beban lateral dikerjakan menggunakan alat double action hydraulic actuator sedangkan beban vertikal dikerjakan di atas setiap kolom sebesar $50 \mathrm{kN}$ dan terus-menerus disesuaikan selama pengujian. Hasil utama dari eksperimen laboratorium adalah grafik hubungan antara beban lateral dan perpindahan untuk specimens, dan pola kegagalan yang terjadi.

Hasil pengujan OF menunjukkan retak pertama terjadi pada bagian bawah kolom, dengan drift $0,4 \%$ diikuti dengan retak balok di dekat permukaan kolom dengan drift $0,6 \%$. Beton kolom hancur diamati pada drift 2,8\%. RDP dengan dinding solid, memberikan perilaku nonlinier dimulai oleh retak dinding pengisi tersebut. Retakan dimulai dalam bentuk retak miring di sudut-sudut tekan atas dengan sudut 45 derajat dan diikuti dengan retak geser horisontal di sepanjang bed joint pertengahan ketinggian dinding dengan drift $0,3 \%$. Selanjutnya, sendi plastis yang diperlihatkan di bagian atas dan bagian bawah kolom dengan drift 1,1\%. Kegagalan specimens didominasi oleh kehancuran diagonal dinding pengisi pada drift $1,9 \%$. Specimens RDP dengan bukaan jendela, mengalami retak diagonal pertama/geser dinding pengisi diamati dengan drift $0,3-0,4 \%$. Sendi plastis diperlihatkan pada bagian atas dan bagian bawah kolom dengan drift 0,3$0,9 \%$. Pola kegagalan pasangan bata terjadi di atas dan di bawah jendela didominasi oleh geser sepanjang bed joint dinding. Specimens RDP dengan bukaan pintu, mengalami retak pertama diagonal /geser dinding pengisi pada drift $0,3 \%$. Sendi plastis diperlihatkan pada bagian atas dan bagian bawah kolom pada drift 0,4-0,6\%. Pola kegagalan pasangan bata terjadi di atas pintu akibat geser sepanjang bed joint dinding. Dinding antara pintu dan kolom gagal akibat dari kekuatan tekan dan tarik baik di tepi atas dan bawah dengan drift $1,2 \%-2,0 \%$. Diantara pintu dan kolom terjadi kehancuran diagonal tekan pada drift 1,5\%-2,7\%.

Sukrawa et al. (2014) melakukan analisis struktur RDP menggunakan model seperti pengujian eksperimen dari Kakaletsis \& Karayannis (2009). Struktur dimodel dua dimensi, dimana balok dan kolom dimodel dengan elemen frame sedangkan dinding dimodel dengan elemen shell. Dari analisis, diperoleh hasil berupa grafik hubungan beban lateral dan deformasi. Hasil ini dibandingkan dengan hasil eksperimen Kakaletsis \& Karayannis (2009). Hasil analisis sudah mampu menirukan perilaku struktur dengan baik sesuai hasil pengujian laboratorium.

Pada model OF perbedaan jelas terlihat pada beban lateral puncak sebesar $44,5 \mathrm{kN}$, dengan nilai deformasi yang lebih besar terjadi pada model (MB). Ini dikarenakan beban lateral yang dikerjakan pada analisis berupa beban statik satu arah sedangkan pada pengujian di laboratorium dilakukan dengan beban siklik

Hasil model RDP penuh (MS) lebih lemah yaitu pada beban $70 \mathrm{kN}$, deformasi pada MS lebih besar $55,014 \%$ daripada eksperimen. Pada deformasi sebesar $5 \mathrm{~mm}$ model MS memiliki kekakuan 1,61 kali dari model MB, model RDP dengan lubang jendela sentris memiliki kekakuan 1,38-1,47 kali dari model MB, sedangkan model RDP dengan lubang pintu sentris memiliki kekakuan 1,23-1,31 kali dari model MB. Untuk model RDP lubang jendela dan pintu eksentris memiliki kekakuan masing-masing 1,56 dan 1,45 kali dari model MB. Dari hasil seluruh model terlihat bahwa keberadaan dinding dalam struktur rangka, bagaimanapun bentuknya tetap memberikan sumbangan kekakuan terhadap struktur RDP. Tetapi, dengan adanya lubang pada dinding pengisi dapat mengurangi kekakuan struktur tersebut. Parameter lubang pada 
dinding yang mengurangi kekakuan berupa bentuk, ukuran, dan posisi lubang. Struktur RDP dengan lubang jendela lebih kaku daripada pintu.

Model RDP dengan lubang jendela sentris, dimana lebar lubang antara 25\%-50\% dari panjang dinding pengisi menyebabkan pengurangan rata-rata $11,2 \%$ terhadap kekakuan RDP dinding solid. Model RDP dengan lubang pintu sentris, dimana lebar lubang antara 25\%-50\% dari panjang dinding pengisi menyebabkan pengurangan rata-rata $20,6 \%$ terhadap kekakuan RDP dinding solid. Untuk model RDP lubang jendela dan pintu eksentris menyebabkan pengurangan masing-masing 2,9\% dan $9,7 \%$ terhadap kekakuan RDP dinding solid. Secara umum terlihat, semakin besar lebar dan luas lubang semakin mengurangi kekakuan yang terjadi pada struktur. Namun, struktur RDP dengan posisi lubang eksentris memiliki struktur lebih kaku daripada posisi lubang sentris.

Pemodelan struktur rangka dinding pengisi dengan elemen shell mendapatkan nilai tegangan yang diperoleh dari pengamatan kontur tegangan yang terjadi. Terdapat lima pola keruntuhan yang sering terjadi pada RDP, yaitu Kehancuran daerah sudut, CC (Corner Crushing), Keruntuhan geser, SS (Sliding Shear), Keruntuhan tekan diagonal, DC (Diagonal Compression), Keruntuhan retak diagonal, DK (Diagonal Craking), dan Keruntuhan Rangka, FF (Frame Failure).

Tegangan tarik maksimum Model MS terjadi pada sudut dinding pertemuan antara kolom dan balok bawah bagian kiri, dengan nilai sebesar 4,307 $\mathrm{N} / \mathrm{mm}^{2}$. Untuk tegangan tekan maksimum terjadi pada sudut dinding pertemuan antara kolom dan balok bawah bagian kanan, dengan nilai sebesar $4,366 \mathrm{~N} / \mathrm{mm}^{2}$. Tegangan geser maksimum model MS terjadi pada bagian tengah dinding sebesar 1,02 $\mathrm{N} / \mathrm{mm}^{2}$.

Untuk model dengan dinding berlubang terjadi kehancuran dinding pada sudut-sudut pertemuan antara balok dengan kolom dan sekitar lubang. Kelima pola kegagalan dialami model dengan lubang eksentris. Model DX1 (MDX1) mengalami tegangan geser maksimum pada sekitar sudut atas bukaan pintu bagian kiri sesuai dengan pola kegagalan SS yang terjadi pada hasil pengujian laboratorium. Untuk pola kegagalan DC pada hasil pengujian juga sesuai dengan hasil analisis, tegangan tekan maksimum terjadi bagian atas kiri pada dinding.

\section{Metode Analisis}

Analisis pada penelitian ini menggunakan software LUSAS (2016) untuk melakukan kajian perilaku rangka dengan dinding pengisi. Pemodelan dilakukan terhadap struktur rangka beton bertulang dengan dinding pengisi (RDP) menggunakan elemen bidang (plane stress) untuk dinding sedangkan elemen frame untuk balok dan kolom. Analisis dilakukan pada struktur RDP merujuk ke pengujian laboratorium oleh Kakaletsis \& Karayannis (2009). Hasil analisis diharapkan dapat menirukan hasil pengujian laboratorium tersebut dan juga hasil analisis menggunakan SAP 2000 yang dilakukan oleh Sukrawa et al. (2014). Tipikal model ditunjukkan pada Gambar 1.
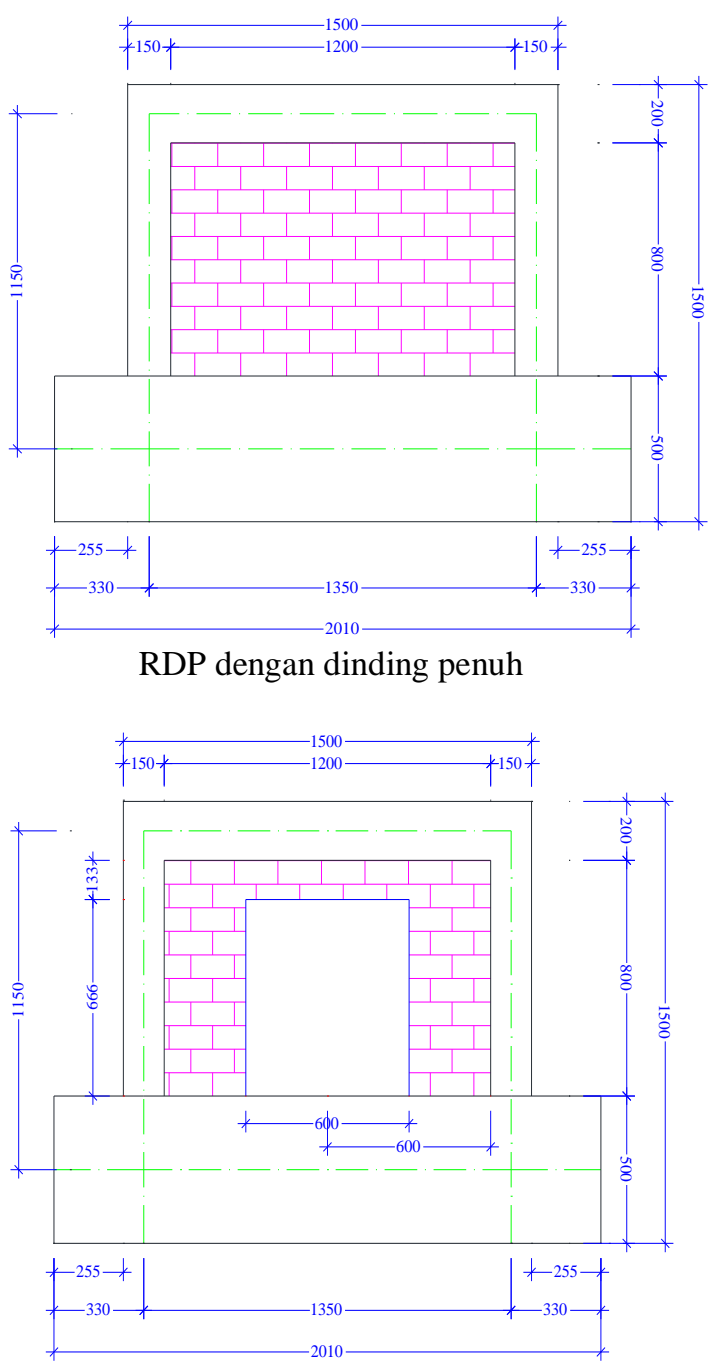

RDP dengan lubang pintu

Gambar 1. Tipikal model yang dianalisis

\section{Properti dan beban}

Geometri struktur dan properti material yang digunakan sebagai model mengacu pada penelitian Kakaletsis \& Karayannis (2009). Beban yang bekerja yaitu berupa beban vertikal yang bekerja pada ujung atas kolom masing-masing sebesar 50 $\mathrm{kN}$ dan beban lateral yang ditingkatkan bertahap. Berbeda dengan eksperimen yang menggunakan beban lateral siklik (menggunakan double action 
hydraulic actuator) dalam analisis ini digunakan pembebanan statik satu arah dengan mengambil nilai beban lateral berdasarkan grafik hubungan lateral load dan lateral displacement envelopes.

\section{Non-linier material}

Material yang dipakai pada analisis pemodelan menggunakan LUSAS yaitu material elastis dan elastis plastis (non linier). Material elastis bisa diaplikasikan untuk seluruh jenis elemen dan analisis yang digunakan, sedangkan material elastis plastis terbatas dipilih untuk jenis elemen tertentu. Pada pemodelan ini dilakukan kajian penggunaan material elastis plastis pada rangka beton bertulang (OF), rangka beton bertulang dengan dinding pengisi (RDP), dan rangka beton bertulang dengan dinding pengisi berlubang. Material yang digunakan yaitu elastic plastic concrete smoothed multi cracked (model 102) dan elastic plastic stress potential von mises.

\section{Langkah-langkah pemodelan struktur pada program LUSAS}

Langkah-langkah pemodelan struktur pada program LUSAS adalah sebagai berikut:

Menentukan geometri model: menentukan gambar model rangka beton menggunakan elemen bidang untuk mewakili rangka beton pada model RB maupun dinding pengisi pada model RDP. Pada model rangka beton dengan dinding yang memiliki lubang digunakan elemen garis (beam element) untuk beton dan elemen plane stress untuk dinding.

Mendefinisikan material dan section properties: Pada tahap ini, mendefinisikan mutu material yang digunakan dalam model dengan pilihan definematerials. Memasukkan data material seperti modulus elastisitas beton (E), modulus elastisitas dinding pengisi (Em), dan poisson ratio (v), untuk analisis menggunakan material elastis. Analisis menggunakan material elastis plastis menggunakan input tambahan seperti kuat tekan beton ( $f$ 'c), regangan puncak beton, tegangan tarik beton. Karakteristik dinding pengisi berupa kuat tekan dinding pengisi (fm), regangan puncak dinding, tegangan tarik dinding.

Untuk elemen beam pada struktur rangka beton bertulang seperti kolom dan balok diberikan input berupa dimensi penampang yang digunakan. Untuk pemodelan dinding pengisi terdapat elemen join untuk sambungan balok dengan dinding pengisi dan kolom dengan dinding pengisi.
Untuk dinding pengisi yang dimodel dengan plane element, gap antara rangka dan dinding dimodel dengan support stiffness pada joint untuk mensimulasi interaksi yang terjadi antara rangka dan dinding pengisi. Nilai kekakuan dihitung menggunakan persamaan (1) pada Dorji (2009) dan didapat nilai $\mathrm{Kg}$ sebesar $1.867 \mathrm{~N} / \mathrm{mm}$.

\section{Hasil dan Pembahasan}

Kajian perilaku struktur rangka beton bertulang dengan dinding pengisi (RDP) dilakukan dengan memodel sebanyak sepuluh struktur RDP menggunakan LUSAS untuk dibandingkan dengan hasil pengujian laboratorium oleh Kakaletsis \& Karayannis (2009) dan analisis menggunakan program SAP oleh Sukrawa et al. (2014). Material non linier yang digunakan seperti pada Tabel 1

Tabel 1. Properti material concrete smoothed multi crack (model 102)

\begin{tabular}{|c|c|c|}
\hline & Beton & Dinding \\
\hline $\begin{array}{l}\text { Young's modulus (E) } \\
(\mathrm{MPa})\end{array}$ & 27.000 & 600 \\
\hline Poisson's ratio (v) & 0,2 & 0,2 \\
\hline $\begin{array}{l}\text { Uniaxial compressive } \\
\text { strength }(\mathrm{MPa})\end{array}$ & 28,5 & 3 \\
\hline $\begin{array}{l}\text { Uniaxial tensile } \\
\text { strength }(\mathrm{MPa})\end{array}$ & 2,85 & 0,03 \\
\hline $\begin{array}{l}\text { Strain at peak } \\
\text { Uniaxial compression }\end{array}$ & $2,2 \mathrm{E}-3$ & $7,5 \mathrm{E}-3$ \\
\hline $\begin{array}{l}\text { Strain at end of } \\
\text { softening curve }\end{array}$ & 0,3 E-3 & $5,5 \mathrm{E}-3$ \\
\hline
\end{tabular}

\section{Model open frame (RB)}

Beton dimodel menggunakan elemen tipe plane stress, element shape quadrilateral, dan menggunakan interpolation order quadratic. Properti material yang digunakan yaitu linier dan analisis linier dengan interval beban $1 \mathrm{kN}$. Hasil analisis pada model open frame (RB) ditunjukkan pada Gambar 2. Simpangan yang terjadi pada beban $30 \mathrm{kN}$ sebesar $24 \mathrm{~mm}$, sesuai dengan hasil eksperimen. Tegangan maksimum terjadi pada ujung bawah pertemuan balok kolom dan tegangan geser terjadi pada pertemuan kolom dan balok atas maupun bawah.

Pada Gambar 3 ditampilkan hasil analisis yang dilakukan pada model RB namun menggunakan material dan analisis non-linier. Kurva beban dan simpangan berperilaku non linier namun besar beban dan simpangan sangat kecil dibandingkan model yang linier (Gambar 2). Posisi retak yang terjadi ditunjukkan pada Gambar 4 (c) yang sesuai dengan hasil ekperimen. 


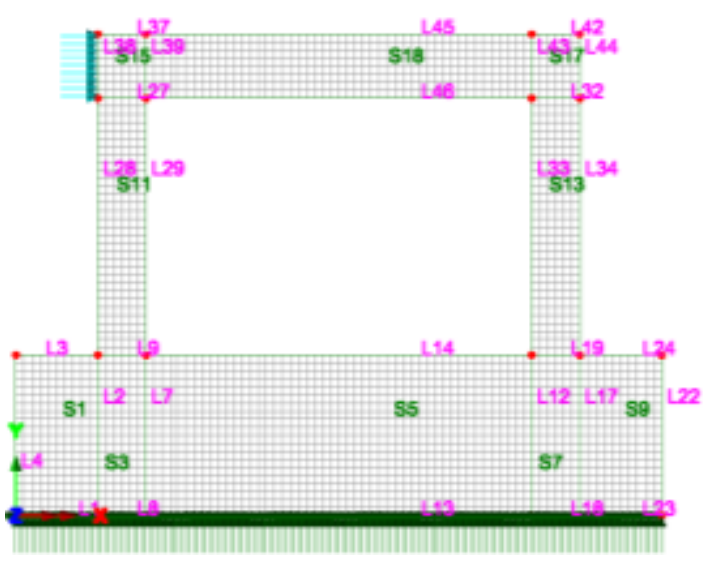

a. Model

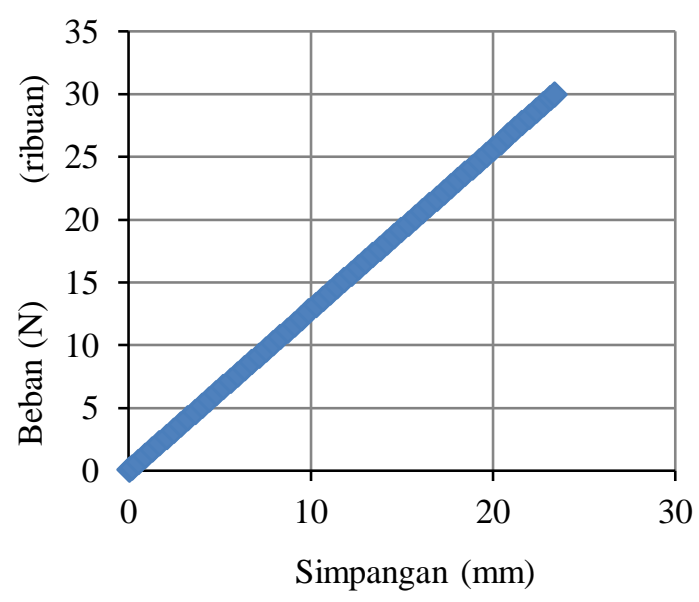

b. Kurva beban simpangan

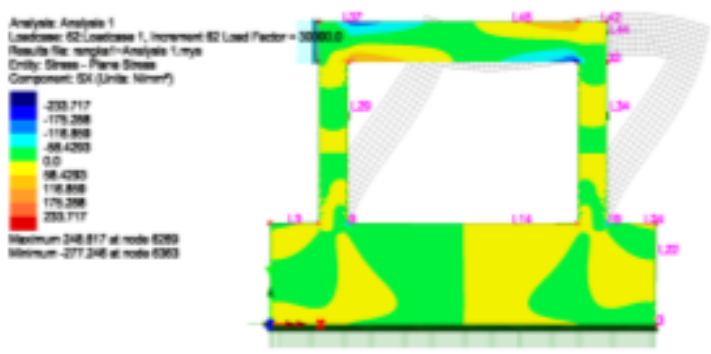

c. Kontur tegangan arah X (Sx)

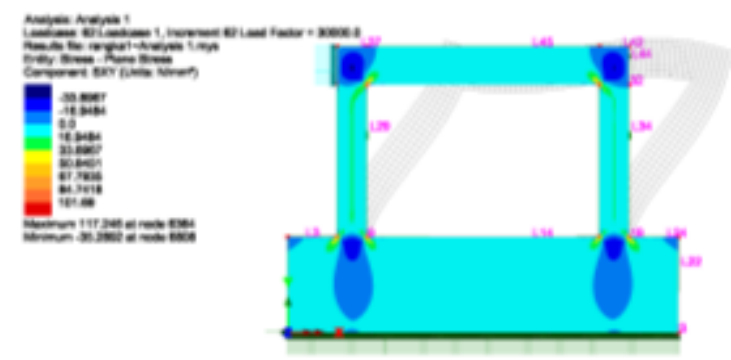

d. Kontur tegangan geser (Sxy) Gambar 2. Model RB

Pada Gambar 4 ditampilkan hasil analisis RBLS yaitu model RB dengan analisis non linier dan menggunakan property material elastic plastic Stress potential von mises dengan nilai E 27000 $\mathrm{MPa}$, Initial uniaxial yield stress $15 \mathrm{MPa}$, Hardening gradient slope $3793,49 \mathrm{MPa}$, dan Hardening gradient plastic strain 5,7 E-30.

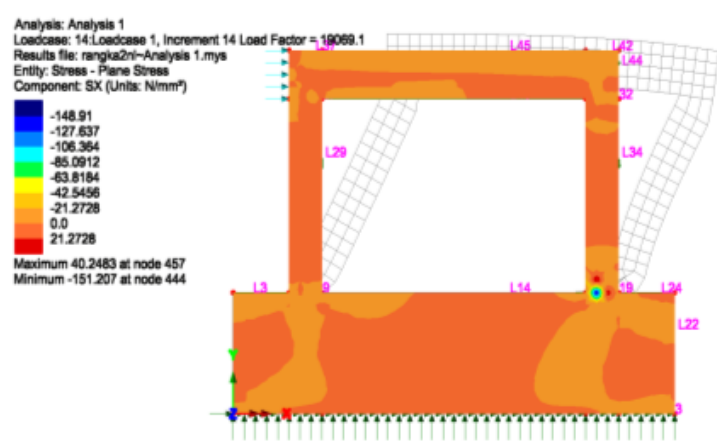

a. Kontur tegangan Sx

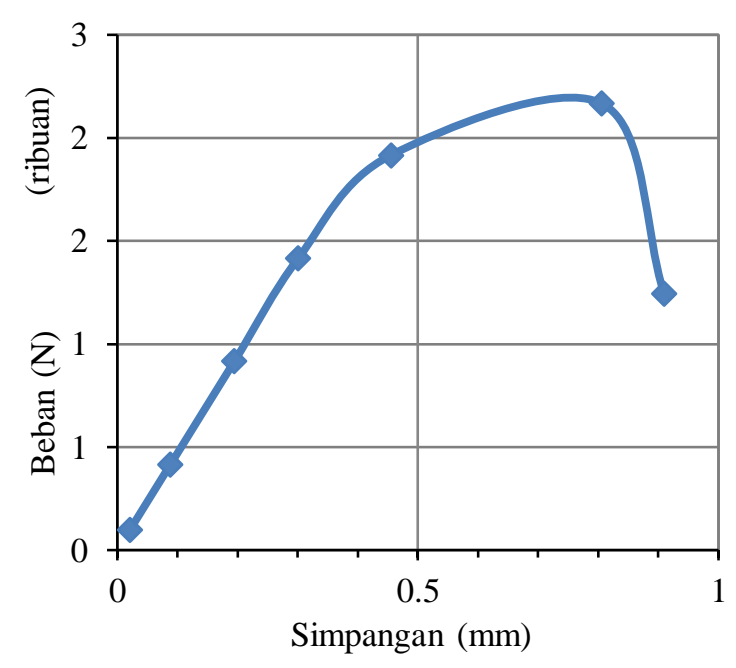

b. Kurva beban simpangan

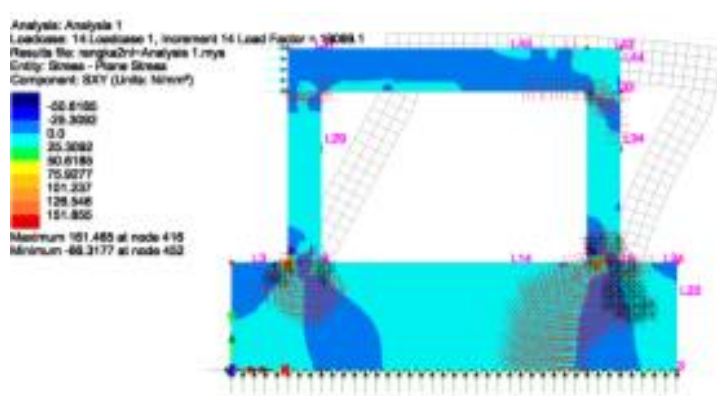

\section{Kontur tegangan Sxy dengan posisi crack}

Gambar 3. Model RBLN

Hasil analisis model RBLS menghasilkan kurva beban dan simpangan non linier, berbeda bila dibandingkan dengan model menggunakan material concrete smoothed multi crack (Gambar 2) tetapi nilai simpangan maksimum pada beban $30 \mathrm{kN}$ sama. Tegangan yang dihasilkan lebih sesuai dengan besar tegangan beton. 


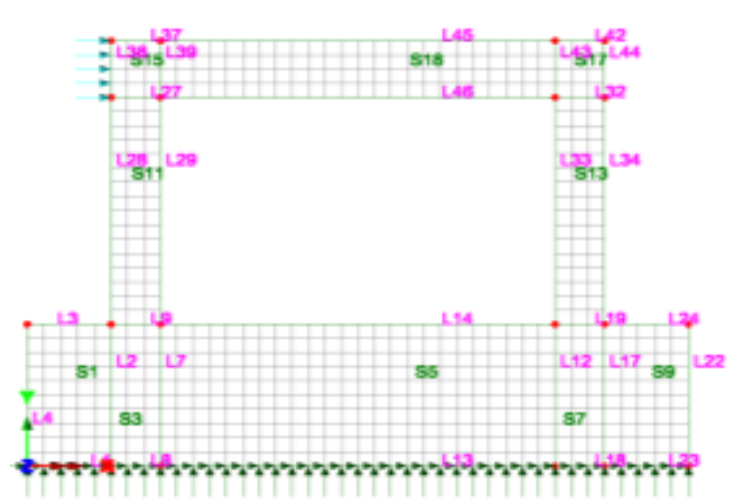

a. Model

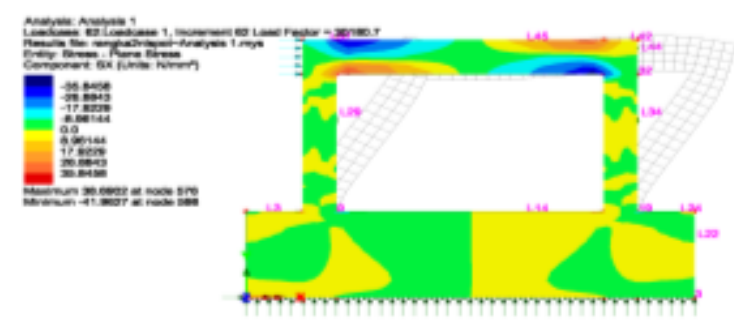

c.Kontur tegangan Sx

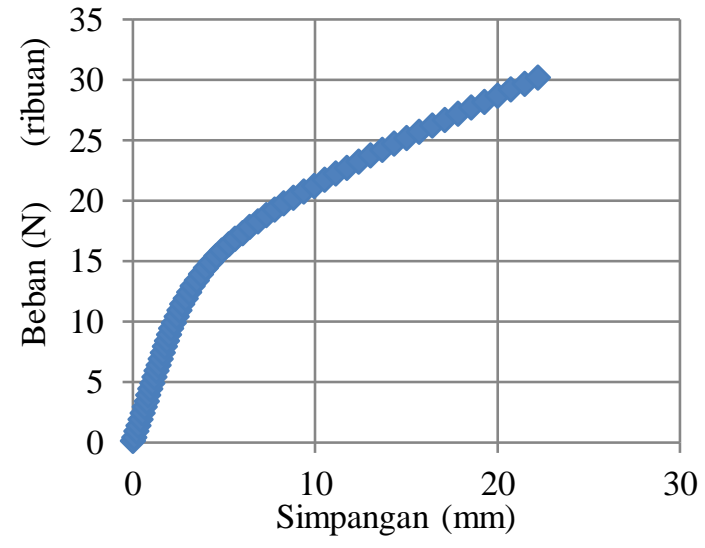

b. Kurva beban simpangan

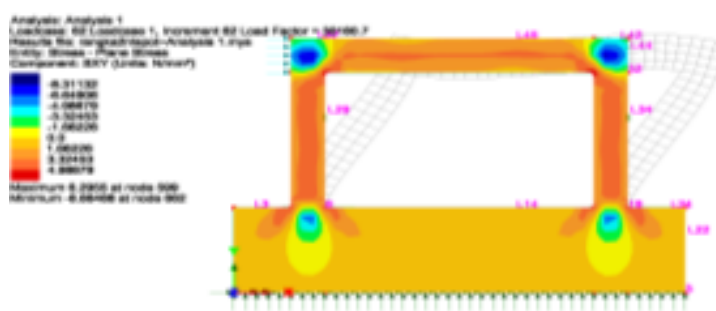

d. Kontur tegangan Sxy

Gambar 4. Model RBLS

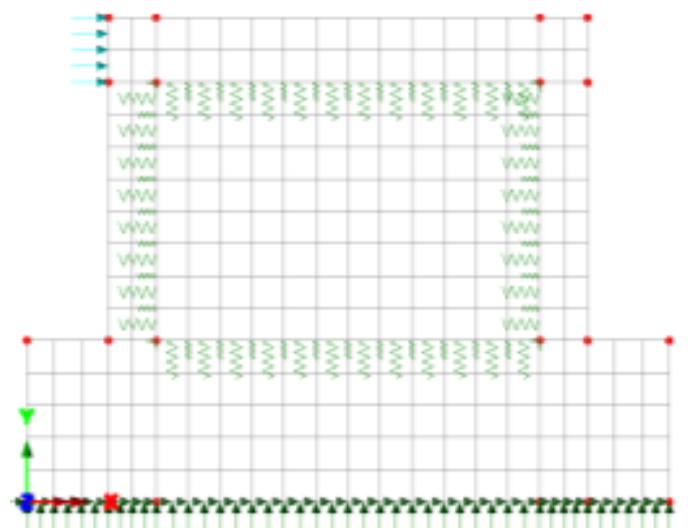

a. Model

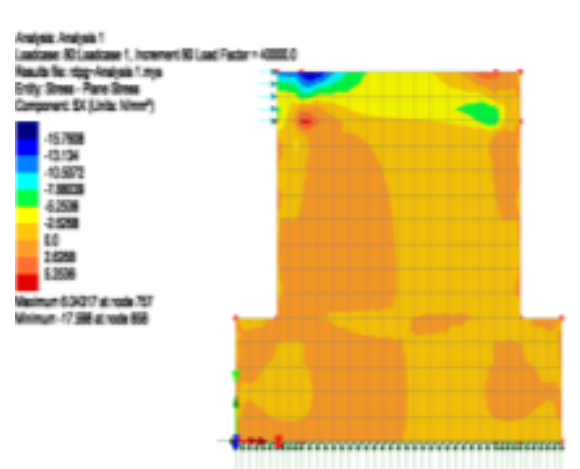

c.Kontur tegangan Sx

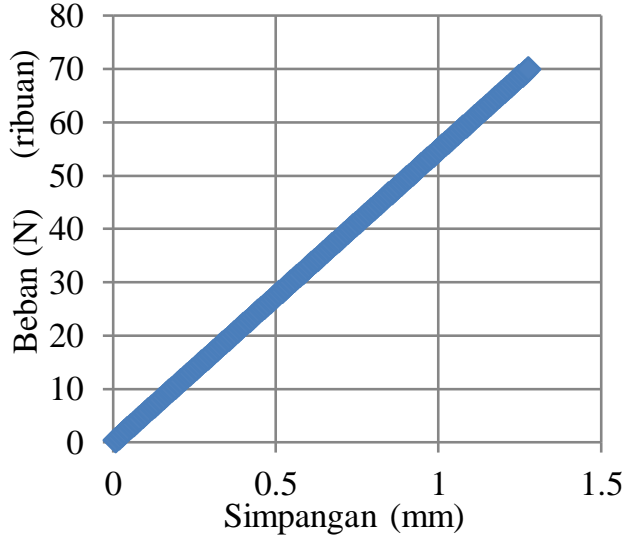

b. Kurva beban simpangan

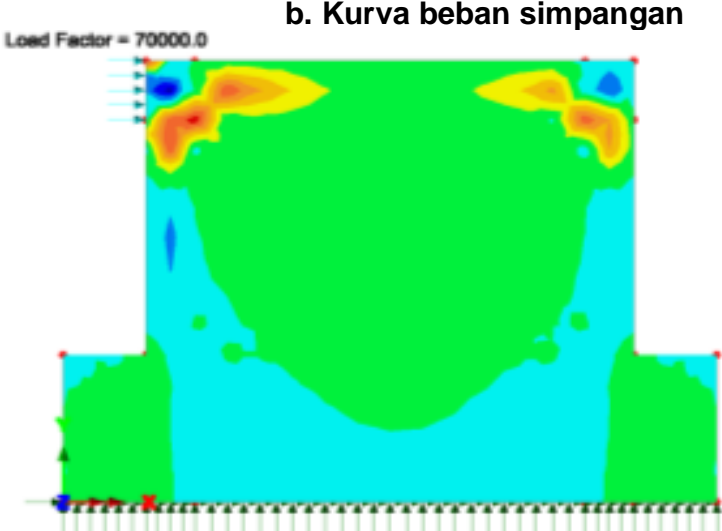

d. Kontur tegangan Sxy

Gambar 5. Model RDP 


\section{Model rangka dinding pengisi (RDP)}

Pada Gambar 5 ditampilkan hasil analisis RDP yang memperhitungkan adanya interaksi antar dinding dan beton dengan mengaplikasikan stiffness support berupa nilai kekakuan Ki sebesar 1867 N/m, dihitung menggunakan persamaan yang diusulkan oleh Dorji (2009). Analisis linier yang dilakukan menghasilkan simpangan berbanding lurus dengan beban.

Gambar 6 menampilkan hasil analisis RDPG yaitu model RDP yang memperhitungkan model kolom sebagai elemen garis (beam element). Properti material yang diaplikasikan yaitu material linier.

\section{Model rangka dengan dinding pengisi berlubang (RDPL)}

Pada pemodelan dengan memperhitungkan dinding berlubang kolom dan balok beton dimodel menggunakan elemen garis (beam element) thin beam, 2 dimensional dan interpolasi quadratic. Perhitungan hubungan beton dan dinding masonry dipergunakan joint element dengan tipe joint no rotational stiffness 2 dimensional dengan linear interpolation menggunakan material elastic spring stiffness sebesar 1,867 E3 N/mm. Dinding masonry dimodel menggunakan element plane stress, quadrilateral and linear interpolation. Properti material digunakan seperti pada Tabel 2.

Tabel 2. Properti material elastic plastic stress potential, von mises

\begin{tabular}{lcc}
\hline & Concrete & Dinding \\
\hline $\begin{array}{l}\text { Young's modulus (E) } \\
(M P a)\end{array}$ & 27.000 & $600 \mathrm{MPa}$ \\
$\begin{array}{l}\text { Poisson's ratio (v) } \\
\text { Initial uniaxial yield } \\
\text { stress }(\mathrm{MPa})\end{array}$ & 0,2 & 0,2 \\
$\begin{array}{l}\text { Slope hardening } \\
\text { gradient }\end{array}$ & 5,11 \\
$\begin{array}{l}\text { Plastic strain } \\
\text { hardening gradient }\end{array}$ & 511 \\
\hline
\end{tabular}

Analisis yang dilakukan adalah non linier. Pada masing-masing kolom dikerjakan beban aksial tekan sebesar $50 \mathrm{kN}$, sesuai dengan eksperimen oleh Kakaletsis \& Karayannis (2009).

Sebanyak delapan model dianalisis yaitu tiga model RDPP1-RDPP3 (rangka beton dengan dinding berlubang sentris untuk pintu), satu model RDPPx (rangka beton dengan dinding berlubang eksentris untuk pintu), tiga model RDPJ1-RDPJ3 (rangka beton dengan dinding berlubang untuk jendela), dan satu model RDPJx (rangka beton dengan dinding berlubang eksentris untuk jendela).

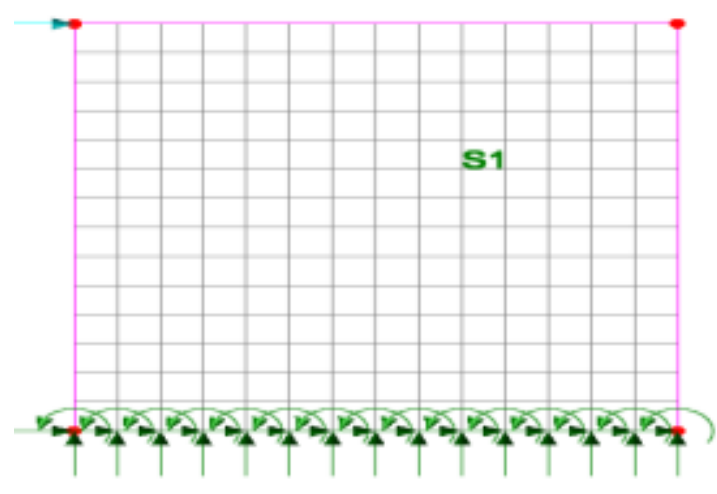

a. Model

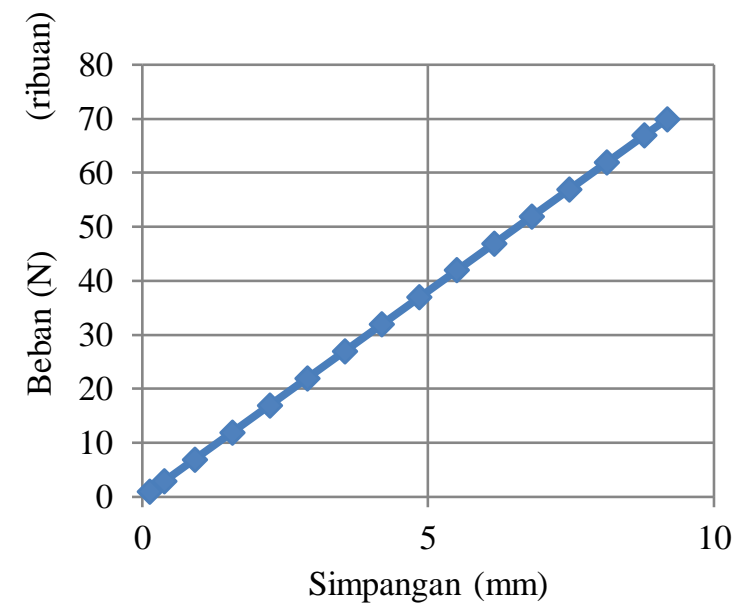

b. Kurva beban simpangan

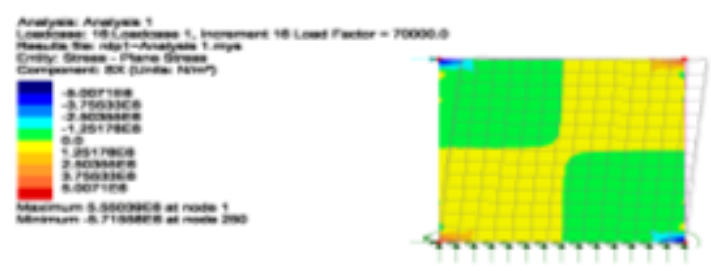

c. Kontur tegangan Sx

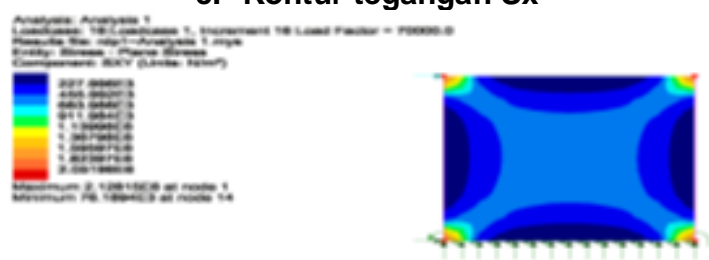

d. Kontur tegangan Sxy

Gambar 6. Model RDPF

Rasio lubang pintu dengan dinding penuh masingmasing sebesar $21 \%, 32 \%$, dan $42 \%$ untuk pintu satu, pintu dua dan pintu tiga. Model dengan lubang eksentris memiliki rasio sama dengan lubang satu tetapi pusat lubang berada di $3 / 4$ panjang dinding. rasio lubang jendela dengan dinding penuh masingmasing sebesar $10 \%, 16 \%$, dan $21 \%$ untuk jendela 
satu, jendela dua, dan jendela tiga. Tipikal hasil analisis seluruh model berupa (a) Kontur tegangan arah $\mathrm{x}(\mathrm{Sx})$ dan (b) Kontur tegangan geser (Sxy) ditampilkan pada Gambar 7.

Pada model rangka beton bertulang, beton dan balok dimodel sebagai elemen bidang (plane stress), material beton dipertimbangkan sebagai material linier elastis dan material elastis plastis (non linear material). Hasil analisis menunjukkan simpangan rangka beton dengan material elastis menunjukkan peningkatan seiring dengan peningkatan beban. Namun, bila material elastis plastis digunakan, baik simpangan maupun tegangan berperilaku non linier. Hasil simpangan dan pola retak beton serupa dengan hasil eksperimen Kakaletsis \& Karayannis (2009).

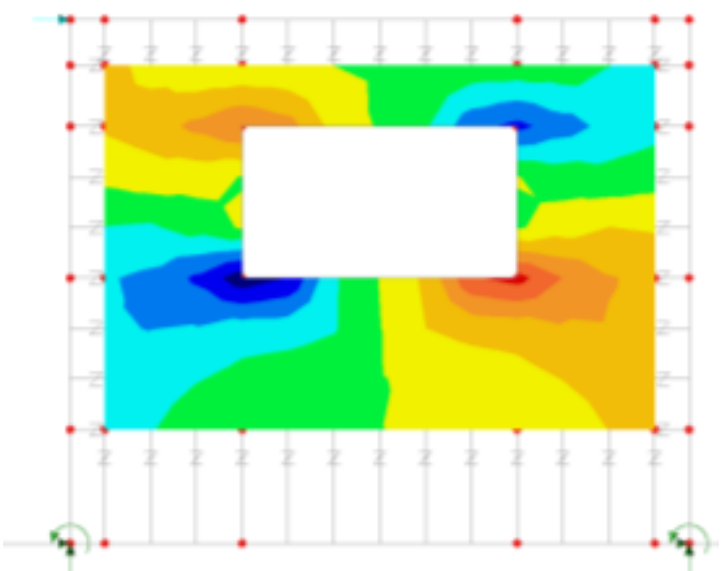

a. Kontur tegangan arah $\mathbf{x}(\mathrm{Sx})$

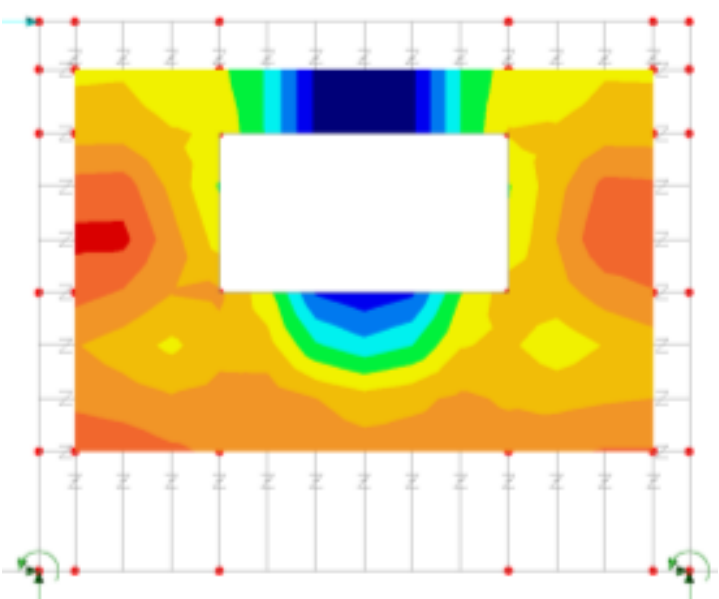

b. Kontur tegangan geser (Sxy)

Gambar 7.Tipikal hasil analisis

Terdapatnya dinding pengisi penuh pada model rangka menyebabkan berkurangnya simpangan struktur, tegangan normal, dan tegangan geser. Pada model dinding berlubang, persentase lubang sebesar $10-40 \%$ dari luas dinding penuh. Hasil analisis menunjukkan terdapat peningkatan simpangan maupun tegangan akibat membesarnya luas lubang. Namun dengan posisi lubang yang eksentris, simpangan yang terjadi lebih kecil dibandingkan model dengan luas lubang yang sama tetapi dengan posisi lubang berbeda.

Pada model dengan dinding berlubang terdapat keterbatasan dalam pemodelan. Material elasis plastis beton tidak bisa dipakai untuk pemodelan satu dimensi. Disamping itu model dengan elemen garis tidak selalu compatible bila digabung dengan model elemen bidang. Akibatnya pada model rangka dengan dinding berlubang digunakan material elastis pada beton sedangkan dinding menggunakan material elastis plastis.

Hasil analisis menunjukkan kurva beban dan simpangan masih bersifat linier dengan beban maksimum sebesar eksperimen. Perilaku ini belum bersesuaian bila dibandingkan dengan hasil eksperimen. Dalam eksperimen beban yang diaplikasikan adalah beban siklik sedangkan pada studi ini diaplikasikan beban monotonik yang ditingkatkan dengan interval tertentu. Bila hasil analisis ini dibandingkan dengan penelitian Sukrawa et al. (2014) terdapat perbedaan yang sangat besar dalam hal besaran simpangan, namun tegangan yang dihasilkan serupa.

\section{Kesimpulan}

Kajian perilaku struktur rangka beton bertulang dengan dinding pengisi (RDP) telah dilakukan dengan memodel struktur RDP menggunakan LUSAS untuk dibandingkan dengan hasil pengujian laboratorium oleh Kakaletsis \& Karayannis (2009). Hasil analisis juga dibandingkan dengan menggunakan program SAP yang dilakukan Sukrawa et al (2014).

Dengan menggunakan program LUSAS hasil analisis RDP berupa tegangan menunjukkan kesesuaian namun terdapat ketidaksamaan besaran simpangan dibandingkan dengan hasil pengujian laboratorium. Hal ini disebabkan karena kesesuaian antara elemen dan material yang yang digunakan dalam analisis belum sepenuhnya bisa diaplikasikan. Perbedaan material nonlinier antara dua elemen yang dipakai belum diakomodasi pada model.

Struktur RDP dengan lubang lebih kecil kekakuannya daripada struktur RDP dinding penuh dengan kecenderungan semakin lebar dan luas lubang semakin berkurang kekakuan struktur. Namun, struktur RDP dengan posisi lubang eksentris lebih kaku daripada struktur RDP dengan lubang sentris. Keberadaan dinding dalam struktur rangka, bagaimanapun bentuknya tetap memberi 
sumbangan kekakuan terhadap struktur RDP. Model analisis dapat menunjukkan titik-titik tegangan maksimum yang terjadi pada dinding sesuai dengan pola kegagalan pada pengujian laboratorium, yaitu terjadi pada sudut lubang dan sudut dinding pertemuan balok dan kolom.

\section{Ucapan Terima Kasih}

Penelitian ini terlaksana dengan biaya dari Program Studi Teknik Sipil Universitas Udayana melalui program Hibah Ketekniksipilan.

\section{Daftar Pustaka}

Agrawal, P., \& Shrikhande, M. (2006). Earthquake resistant design of structures. PHI Learning Pvt. Ltd.

Akhoundi, F., Lourenço, P. B., \& Vasconcelos, G. (2015). Numerically Based Proposals for the Stiffness and Strength of Masonry Infills with Openings in Reinforced Concrete Frames. Earthquake Engineering \& Structural Dynamics, 45(6), 869-891.

Amato, G., Fossetti, M., Cavaleri, L., \& Papia, M. (2009, January). An Updated Model of Equivalent Diagonal Strut for Infill Panels. In Proceedings of Eurocode (Vol. 8, pp. 119-128).

Asteris, P. G. (2008). Finite Element MicroModeling of Infilled Frames. Electronic Journal of Structural Engineering, 8(8), 1-11.

Budiwati, I. A. M., \& Sukrawa, M. (2017). Kinerja Struktur Rangka Beton Bertulang dengan Penambahan Dinding Pengisi Berlubang sebagai Perkuatan Seismik. Journal of Civil Engineering, 24(1), 43-50.
Dorji, J. (2009). Seismic Performance of Brick Infilled RC Frame Structures in Low and Medium Rise Buildings in Bhutan, Thesis Master of Engineering, Queensland University of Technology.

Kakaletsis, D. J., \& Karayannis, C. G. (2009). Experimental Investigation of Infilled Reinforced Concrete Frames with Openings. ACI Structural Journal, 106(2).

Kaushik, H. B., Rai, D. C., \& Jain, S. K. (2007). Stress-Strain Characteristics of Clay Brick Masonry under Uniaxial Compression. Journal of materials in Civil Engineering, 19(9), 728-739.

LUSAS. (2016). Engineering Analysis and Design Software, Surrey, UK.

Meharbi, A. B., \& Shing, P. B. (2003). Seismic Analysis of Masonry-Infilled Reinforced Concrete Frames. TMS Journal, 21, 81-94.

Mondal, G., \& Jain, S. K. (2008). Lateral Stiffness of Masonry Infilled Reinforced Concrete (RC) Frames with Central Opening. Earthquake spectra, 24(3), 701-723.

Samoilă, D. M. 2012. Analytical modelling of masonry infills. Acta Technica Napocensis: Civil Engineering \& Architecture, 55, 127-136.

Sigmund, V., \& Penava, D. (2013). Assessment of masonry infilled reinforced-concrete frames with openings. Technical Gazette, 20(3), 459-466.

Sukrawa, M., Budiwati, I. A. M. \& Agus-Sarjana, I. G. (2014). Kajian perilaku struktur rangka dengan dinding pengisi berlubang, Laporan Penelitian Hibah Ketekniksipilan. Badung 